\title{
Penerapan Akuntansi Pada Usaha Mikro Kecil dan Menengah (UMKM) Khususnya Usaha Kemplang Krupuk Ikan Gabus Mang Arsyad dan UMKM Pempek Kemplang Krupuk Nona
}

\author{
Saekarini Yuliachtri, Rosalina Ghozali, Darma Yanti, Nina Sabrina \\ Universitas Muhammadiyah Palembang \\ rinisaekarini@gmail.com
}

Submitted: $31^{\text {st }}$ July 2019. Revised: $11^{\text {th }}$ October 2019. Accepted: $31^{\text {st }}$ October 2019

Key word:

Training;

Implementation,

Accounting

Process,

Financial

Statement

\section{Kata Kunci}

Pelatihan,

Penerapan,

Proses

Akuntansi,

Laporan

Keuangan

\section{Abstract}

Partners in the implementation of this service Kemplang UMKM Gabus Fish Krupuk Mang Arsyad and UMKM Pempek Kemplang Krupuk Nona located in the jayalaksana hall of the village 3-4 Ulu subdistrict opposite ulu 1. Based on the situation analysis, it can be identified several problems faced by partners, namely: The level of management and accounting knowledge is very minimal in both partners. This is motivated by the level of education of partner managers who are educated with junior high school education and the highest senior high school. The implementation method used in conducting school management management activities as well as structuring school financial statement structuring consists of 2 stages. namely stage 1 delivery of material, stage 2 guidance and assistance in preparing financial statements. UMKM accounting training activities for micro, small and medium enterprises (UMKM) to improve the company's financial performance run smoothly. All participants enthusiastically participated in the event until it was finished and felt the benefits of training for their business progress, gradually the process of preparing financial statements began to be carried out in the mentoring stage.

\section{Abstrak}

Mitra dalam pelaksanaan pengabdian ini UMKM Kemplang Krupuk Ikan Gabus Mang Arsyad dan UMKM Pempek Kemplang Krupuk Nona yang berlokasi di lorong jayalaksana kelurahan 3-4 Ulu kecamatan seberang ulu 1.Berdasarkan analisis situasi dapat teridentifikasi beberapa masalah yang dihadapai mitra, yaitu: Tingkat pengetahuan manajemen dan akuntansi sangat minim di kedua mitra hal ini dilatarbelakangi tingkat pendidikan para pengelola mitra yang berpendidikan berpendidikan sekolah menengah pertama dan paling tinggi sekolah menengah atas.

Metode pelaksanaan yang digunakan dalam melakukan kegiatan pembinaan pengelolaan manajemen sekolah serta pembinaan penataan laporan keuangan sekolah terdiri dari 2 tahapan. yaitu tahap 1 penyampaian materi, tahap 2 bimbingan dan pendampingan penyusunan laporan keuangan. Kegiatan pelatihan akuntansi UMKM bagi usaha mikro, kecil, menengah (UMKM) untuk meningktakan kinerja keuangan perusahaan berjalan dengan lancar. Semua peserta antusias mengikuti acara hingga selesai dan merasakan manfaat pelatihan bagi kemajuan usaha mereka, secara bertahap proses penyusunan laporan keuang mulai dijalankan dalam tahapan pendampingan. 


\section{PENDAHULUAN}

UMKM adalah singkatan dari Usaha Mikro, Kecil dan Menengah. Dalam pelaksanaannya, UMKM menerapkan asas kebersamaan, ekonomi yang demokratis, kemandirian, keseimbangan kemajuan, berkelanjutan, efisiensi keadilan, serta kesatuan ekonomi nasional. Di Indonesia, hari UMKM Nasional diperingati setiap tanggal 31 Maret. UMKM adalah usaha kerakyatan yang saat ini mendapat perhatian dan keistimewaan yang diamanatkan oleh Undang-undang, antara lain bantuan kredit usaha dengan bunga rendah, kemudahan persyaratan izin usaha, bantuan pengembangan usaha dari lembaga pemerintah, serta beberapa kemudahan lainnya. Bidang-bidang UMKM beragam mulai dari fashion, kuliner, kerajinan hingga pertanian.

Dalam perekonomian Indonesia, Usaha Mikro, Kecil, dan Menengah (UMKM) adalah kelompok usaha yang memiliki jumlah paling besar. Selain itu, kelompok ini terbukti tahan terhadap berbagai macam goncangan krisis ekonomi. Maka sudah menjadi keharusan untuk melakukan penguatan kelompok UMKM yang melibatkan banyak kelompok. Kriteria usaha yang termasuk dalam UMKM telah diatur dalam payung hukum berdasarkan undang-undang.

Salah satu tantangan utama yang dihadapi oleh wirausahawan UMKM adalah terkait dengan pengelolaan dana. Pengelolaan dana yang baik merupakan faktor kunci yang dapat menyebabkan keberhasilan atau kegagalan UMKM. Meskipun banyak faktor lain yang mempengaruhi UMKM tetapi persoalanpersoalan di UMKM lazimnya muncul akibat kegagalan mengelola dana. Metode praktis dan manjur dalam pengelolaan dana pada UMKM adalah dengan menerapkan akuntansi dengan baik. Dengan demikian, akuntansi menjadikan UMKM dapat memperoleh berbagai informasi keuangan yang penting dalam menjalankan usahanya. Informasi keuangan yang dapat diperoleh UMKM antara lain informasi kinerja perusahaan, informasi penghitungan pajak, informasi posisi dana perusahaan, informasi perubahan modal pemilik, informasi pemasukan dan pengeluaran kas.

Sebagian besar pengusaha tidak mengetahui laba yang didapatkan, mereka menjawab bukan dengan nominal angka rupiah melainkan dengan benda-benda berwujud seperti motor, rumah, atau mobil. Jawaban tersebut tidak menggambarkan laba yang sebenarnya didapatkan oleh perusahaan karena itu merupakan salah satu penggunaan dana yang mungkin 
didanai dari laba atau justru dari utang ataupun pengambilan modal pemilik. Faktor lain yang dihadapi para UMKM adalah tingkat pendidikan baik pemilik maupun karyawan yang kebanyakan tidak berpendidikan strata satu. Hal ini sangat mempengaruhi sistem pengelolaan keuangan UMKM tersebut.

Laporan Keuangan UMKM serta latar belakang pendidikan dari pengusaha UMKM terhadap pemahaman atas SAK ETAP. Penelitian yang telah dilakukan di Salatiga menunjukkan bahwa jenjang pendidikan yang lebih tinggi mampu meningkatkan pemahaman tentang pentingnya melakukan pencatatan dan membuat laporan keuangan (Kurniawati, Nugroho, \& Arifin, 2015).

Pembukuan akuntansi untuk menyajikan laporan keuangan yang dilakukan oleh UMKM akan memberikan informasi yang lebih jelas dengan tujuan memberikan kemudahan bagi investor maupun kreditor untuk memberikan bantuan pembiayaan bagi para pengusaha UMKM (Rudiantoro \& Siregar, 2012).

Usaha Kemplang Krupuk Ikan Gabus Mang Arsyad dan UMKM Pempek Kemplang Krupuk Nona yang berlokasi di lorong Jayalaksana Kelurahan 3-4 Ulu, Kecamatan Seberang Ulu 1 adalah UMKM yang sudah melakukan pencatatan sederhana dari pendapatan dan pengeluaran, akan tetapi belum memperhitungkan asset dan laporan neraca. Menurut pemahaman pemilik UMKM, hal ini disebabkan karena: tingkat pengetahuan manajemen dan akuntansi sangat minim di kedua mitra. Hal ini dilatarbelakangi tingkat pendidikan para pengelola mitra yang berpendidikan berpendidikan sekolah menengah pertama dan paling tinggi sekolah menengah atas

Berdasarkan kondisi ini tim pengabdi melakukan pengabdian tentang penerapan akuntansi pada Usaha Mikro Kecil dan Menengah (UMKM) khususnya usaha. Usaha Kemplang Krupuk Ikan Gabus Mang Arsyad dan UMKM Pempek Kemplang Krupuk Nona yang berlokasi di lorong Jayalaksana Kelurahan 3-4 Ulu, Kecamatan Seberang Ulu 1.

\section{METODE}

Metode Pelaksanaan yang digunakan dalam melakukan kegiatan pembinaan penataan laporan keuangan sekolah terdiri dari 2 tahapan, yaitu :

1. Pembinaan kepada mitra-mitra.

Pembinaan yang akan diterapkan yaitu diawali dengan pelatihan-pelatihan dengan cara pemberian materi-materi laporan keuangan khususnya materi laporan arus kas UMKM yang sesuai dengan SAK ETAP 2011 
2. Bimbingan dan Pendampingan Penyusunan Laporan Keuangan Pendampingan dapat dipahami sebagai kegiatan pemberdayaan masyarakat dengan menempatkan tenaga pendamping sebagai fasilitator, komunikator, motivator dan dinamisator. Pada dasarnya, pendampingan merupakan upaya untuk menyertakan masyarakat dalam mengembangkan berbagai potensi sehingga mampu mencapai kualitas kehidupan yang lebih baik. Selain itu diarahkan untuk memfasilitasi proses pengambilan keputusan yang terkait dengan kebutuhan masyarakat, membangun kemampuan dalam meningkatkan pendapatan, melaksanakan usaha yang berskala bisnis serta mengembangkan perencanaan dan pelaksanaan kegiatan partisipatif.

\section{HASIL DAN PEMBAHASAN}

Pelaksanaan pelatihan dibagi dalam 2 tahap pertama penyampaian materi dan praktik akuntansi selama 1 hari yaitu pada hari Kamis 15 Februari 2018 dari jam 09.00 sampai dengan 17.00. Acara pertama diawali dengan regisrasi dan pembukaan. Selanjutnya, dilanjutkan dengan pemberian materi pertama oleh Ibu Nina Sabrina, S. E, M..M dan Ibu Darma Yanti, S. E, M.M,
Ak, CA dengan topik materi Pengantar Akuntansi UMKM dan Transaksi Akuntansi UMKM. Materi ini membahas pentingnya akuntansi bagi UMKM. Materi pertama ini diakhiri pada pukul 12.00. Acara selanjutnya adalah ISHOMA selama satu jam (12.00-13.00). Setelah ISHOMA, sesi kedua dimulai pada pukul 13.00 dan berakhir pada 15.00. Materi kedua ini juga disampaikan oleh Ibu Nina Sabrina, S. E, M..M dan Ibu darma Yanti, S. E, M.M, Ak, CA dengan topik pelaporan akuntansi UMKM dan praktik akuntansi UMKM Selanjutnya pada pukul 11.30 sampai dengan 13.00 peserta diberi kesempatan untuk ISHOMA. Materi praktik akuntansi UMKM dilanjutkan kembali dari pukul 13.00 sampai dengan 17.00. Pada pelatihan ini peserta diminta mencatat transaksi bisnis berdasarkan bisnis masing-masing dan selanjutnya menyusun laporan keuangan. Pada sesi terakhir ini kegiatan pelatihan diakhiri pada jam 17.00. Selanjutnya sisa pelatihan 7,5 jam digunakan untuk pendampingan kepada peserta pelatihan akuntansi UMKM secara mandiri di masing-masing tempat dalam hal ini tim dibantu oleh anggota tim yaitu mahasiswa KKN

Pelaksanaan pelatihan pada hari Kamis 15 Februari 2018 berjalan dengan lancar. Materi pertama yang diberikan adalah pengenalan atau pendahuluan 
mengenai akuntansi. pemateri memberikan penjelasan pentingnya akuntansi bagi UMKM. Sebagian besar audiens belum mengerti fungsi akuntansi, bahkan sebagian besar peserta pelatihan menganggap bahwa akuntansi adalah bidang yang rumit, susah, merepotkan, menghabiskan waktu. Materi pertama ini diisi dengan penguatan pentingnya akuntansi bagi usaha kecil (UMKM). Pada sesi ini terjadi diskusi yang menarik antara audiens dengan pemateri mengenai konsep dasar usaha. Beberapa audiens memiliki persepsi berebeda tentang usaha atau entitas.

Berdasarkan diskusi konsep entitas ini akhirnya diperoleh pemahaman konsep entitas. Setelah diperoleh kesepakatan tentang konsep entitas, dilanjutkan dengan fungsi pelaporan keuangan bagi entitas. Setelah acara ISHOMA selama satu jam acara dilanjutkan dengan materi kedua mengenai transaksi-transaksi akuntansi UMKM. Pada sesi ini, masingmasing audiens diminta menjelaskan aktivitas operasi masing-masing usaha mereka. Selanjutnya diidentifikasi aktivitasaktivitas ekonomi dan aktivitas nonekonomi. Berdasarkan aktivitas ekonomi yang telah diidentifikasi, selanjutnya dilakukan pencatatan akuntansi. Aktivitas yang diidentifikasi tersebut diawali dari aktivitas memulai usaha (investasi awal), transaksi pembelian bahan baku, pembelanjaan/pengeluaran, pemasukan/penerimaan dll. Setelah mencatat transaksi akuntansi, materi berikutnya menyusun laporan keuangan. Sebagai latihan, peserta pelatihan diminta membuat laporan keuangan sederhana berdasarkan contoh yang ada. Latihan ini berakhir pada pukul 17.00 sore. Sebelum peserta pelatihan pulang, pemateri memberikan tugas berupa identifikasi transaksi yang terjadi di masing-masing usaha mereka sehingga pada saat kegiatan konsultasi langsung ke tempat usaha, tim pemateri dapat langsung membina UMKM. Pada pelatihan ini peserta diminta mengumpulkan mencatat transaksi bisnis berdasarkan bisnis masing-masing yang telah disiapkan dari rumah. Pada tahap awal ini peserta bertanya dan berdiskusi tentang transaksi dan pencatatan yang telah mereka buat. Beberapa dari perserta masih kebingungan mencatat transaksi akuntansi. Sesi pertama ini cukup menyita waktu karena pembahasan transaksi dan pencatatan akuntansi dilakukan satu satu. Setelah semua peserta menyelaikan pencatatan transaksi akuntansi, peserta beristirahat untuk makan siang dan melakukan ibadah siang. Setelah beristirahat diskusi dilanjutkan membahas penyusunan laporan keuangan. Pada sesi terakhir ini peserta diminta menyusun 
laporan keuangan berdasarkan transaksi akuntansi yang telah mereka buat. Pada sesi terakhir ini kegiatan pelatihan diakhiri pada jam 17.00.Selanjutnya sisa pelatihan 7,5 jam digunakan untuk pendampingan kepada pesrta pelatihan akuntansi UMKM secara mandiri di masing-masing tempat.

Faktor Pendukung Kegiatan Secara umum acara pelatihan ini berjalan dengan lancar. Hal ini dicapai berkat dukungan pihak Kelurahan 3-4 ulu dan pihak RT yaitu fasilitas tempat serta bantuan dalam mengumpulkan audiens peserta. Pihak kelurahan, RT dan UMKM menyambut baik acara pelatihan ini sehingga berkeinginan agar kegiatan pelatihan ini tetap berlanjut di masa yang akan datang untuk kemajuan UMKM di wilayah Kelurahan 3-4 Ulu Palembang.

Faktor Penghambat Kegiatan Beberapa hambatan yang dialami pada saat pelatihan antara lain: beberapa anggota UMKM tidak dapat hadir. Namun demikian acara Pengabdian Masyarakat dapat terlaksana dengan lancar karena pembagian tugas telah dilakukan jauh hari sebelum acara ini dilaksanakan. Hambatan lain yang dijumpai tim Pengamdian Masyarakat adalah keikutsertaan atau kehadiran peserta yang relatif rendah hanya 17 peserta yang hadir dari 30 undangan UMKM . Hal ini diduga karena beberapa peserta atau pengusaha Kemplang dan pempek yang diundang memiliki kegiatan di tempat lain, seperti mengikuti pameran di luar kota, pelatihan yang diselenggarakan instansi lain (perindustrian dan perdagangan).

\section{SIMPULAN}

Kegiatan pelatihan akuntansi umkm bagi usaha mikro, kecil, menengah (umkm) untuk meningktakan kinerja keuangan perusahaan berjalan dengan lancar. semua peserta antusias mengikuti acara hingga selesai dan merasakan manfaat pelatihan bagi kemajuan usaha mereka.

Saran pelatihan serupa dapat dilaksanakan kembali dengan peserta (audience) yang lebih banyak/luas, dan dengan topik lainnya. pembinaan berkelanjutan berupa pembinaan penyusunan laporan keuangan umkm berbasis aplikasi seperti aplikasi program microsoft office khususnya microsoft word dan microsoft excel

\section{DAFTAR PUSTAKA}

Al Haryono, J. (2001). Dasar-Dasar Akuntansi, Jilid 1. Yogyakarta: $Y K P N$.

Indonesia, I. A. (2013). Pengantar Akuntansi..

Indonesia, I. A. (2014). Standar Akuntansi Keuangan Entitas Tanpa Akuntabilitas Publik. Jakarta: 


Dewan Standar Akuntansi
Keuangan.

Kurniawati, E. P., Nugroho, P. I., \& Arifin,

C. (2015). Penerapan Akuntansi pada Usaha Mikro Kecil dan Menengah (UMKM). Jurnal

Manajemen dan Keuangan, 10(2).

Rudiantoro, R., \& Siregar, S. V. (2012).

Kualitas laporan keuangan umkm serta prospek implementasi SAK

ETAP. Jurnal Akuntansi dan

Keuangan Indonesia, 9(1), 1-21. 